\title{
POLA KERUKUNAN ANTAR UMAT BERAGAMA DALAM PERSPEKTIF FORUM KERUKUNAN UMAT BERAGAMA (FKUB) SUMATERA UTARA
}

\author{
Manshuruddin \\ Universitas Pembangunan Panca Budi \\ Jl. Jend. Gatot Subroto Km. 4,5, Medan, Sumatera Utara, 20122 \\ e-mail: ryanasofee@gmail.com
}

\begin{abstract}
Abstrak: Penelitian ini bertujuan untuk memahami dinamika pola kerukunan umat beragama (religious harmony) FKUB di Sumatera Utara. Untuk mengungkap hal itu, penelitian ini menggunakan pendekatan phenomenologic-interpretif, dengan menggunakan teknik pengumpulan data pada FGD (Focus Group Discussion). Penelitian ini mengajukan beberapa temuan. Pertama, idealita kerukunan yang dibangun oleh FKUB Sumut berpijak pada pola kerukunan non-pluralisme agama, yang berarti bahwa truth claim pada masing-masing agama tidak bisa disamakan karena memiliki landasan teologis yang berbeda. Namun dalam konteks sosial, kebenaran teologis tersebut tidak boleh dipaksakan kepada orang lain, dan setiap individu beragama harus mampu bekerjasama untuk kepentingan bermasyarakat, berbangsa dan bernegara. Kedua, dalam penerapannya, FKUB Sumatera Utara melakukan dialog teologis, interaksi sosial, advokasi dan regulasi serta dialog interaktif.
\end{abstract}

\begin{abstract}
The Pattern of Religious Harmony in the Perspective of Religious Harmony Forum of Sumatera Utara. This study aims to analyze the dynamics of the harmony of the FKUB (Religious Harmony Forum in North Sumatra). This study uses a phenomenologic-interpretive approach, using data collection techniques in FGD (Focus Group Discussion). This research finds that: First, the ideal of harmony established by FKUB of North Sumatra is based on the pattern of religious non-pluralism harmony, in a sense that the claim of truth in each religion can not beequated because it has a different theological foundation. But in the social context, such theological truths should not be imposed on others, and every religious individual must be able to work together for the benefit of society, nation and state. Second, in its application, FKUB of North Sumatra conducts theological dialogue, social interaction, advocacy and regulation and interactive dialogue.
\end{abstract}

Keywords : agama-agama, kerukunan, pluralisme, FKUB, Sumatera Utara 


\section{Pendahuluan}

Dalam tataran elit agama, setidaknya terdapat dua pola yang ditawarkan dalam mengusung kerukunan antar umat beragama (religious harmony) di Indonesia. Pertama, pluralisme agama (religious pluralism), yang didasarkan pada asumsi bahwa sumber konflik yang selama ini terjadi di Indonesia adalah karena adanya klaim kebenaran (truth claim) masing-masing agama. Untuk itu perlu penyelarasan pandangan seluruh penganut agama bahwa pada hakikatnya semua agama itu sama. Kedua, non-pluralisme agama, yang merupakan pola oposisi terhadap pluralisme agama. Pola ini mengakui bahwa keragaman atau pluralitas adalah sebuah keniscayaan yang tidak dapat ditolak, namun tidak mengakui bahwa semua agama itu sama. Sebab, dalam agama-agama terdapat klaim teologis yang tidak bisa diganggu gugat. Seluruh agama boleh mengakui kesalahan teologi agama yang lain, tetapi hal itu tidak berarti boleh memaksakan orang yang beragama lain masuk ke agama yang dianut, serta membiarkan mereka melaksanakan ajarannya masing-masing dengan aturan-aturan yang telah disepakati bersama di Negara Kesatuan Republik Indonesia. Biasanya paham ini diusung oleh sebagian besar para pemuka agama.

Forum Kerukunan Umat Beragama (FKUB) Sumatera Utara adalah sarana yang difasilitasi oleh Pemerintah dalam rangka membangun, memelihara dan memberdayakan umat beragama untuk kerukunan dan kesejahteraan di wilayah Sumatera Utara. Karena itu, penting untuk melihat posisi FKUB Sumatera Utara di antara kedua pola tersebut, sehingga dapat diketahui idealita kerukunan yang dibangun oleh mereka dan bagaimana penerapannya dalam konteks Sumatera Utara. Hal ini penting untuk melihat apakah ada kesesuaian antara idealita yang dibangun dengan penerapannya di lapangan. Penelitian ini mengambil objek elit agama di FKUB wilayah provinsi Sumatera. Ini dipilih karena Sumatera Utara memiliki masyarakat yang multikultural, ${ }^{1}$ dan oleh karena tingkat provinsi, FKUB Sumatera Utara dapat dijadikan sebagai representasi pandangan elit agama-agama di FKUB tingkat Kabupaten/Kota.

\section{Metode Penelitian}

Jenis penelitian ini adalah kualitatif dengan pendekatan phenomenologic-interpretif.

\footnotetext{
${ }^{1}$ Agama Islam terutama dipeluk oleh suku Melayu, Pesisir, Minangkabau, Jawa, Aceh, Suku Batak Mandailing, sebagian Batak Karo, Simalungun dan Pakpak (65, 45 \%). Agama Kristen (Katolik dan Protestan) terutama dipeluk oleh suku Batak Karo, Toba, Simalungun, Pakpak, Mandailing, dan Nias (31,30 \%). Agama Hindu terutama dipeluk oleh suku Tamil di perkotaan $(0,19 \%)$. Agama Budha terutama dipeluk oleh suku peranakan Tionghoa di perkotaan $(2,28 \%)$. Agama Konghucu terutama dipeluk oleh suku peranakan Tionghoa di perkotaan (0,14\% termasuk kepercayaan yang lain). Agama Parmalim dipeluk oleh sebagian suku Batak yang berpusat di Huta Tinggi, Kecamatan Lagu Boti, kabupaten Toba Samosir. Agama Animisme dan Dinamisme masih ada dipeluk oleh suku Batak dan suku Karo, yaitu Pelbegu Parhabonaron dan kepercayaan sejenisnya. Lihat BPS Provinsi Sumatera Utara, Sumatera Utara dalam Angka (Medan: BPS Sumatera Utara, 2013).
} 
Phenomenology yang dimaksud adalah phenomenology-nya Edmund Husserl (1859-1938), dimana dikemukakan bahwa objek ilmu tidak terbatas pada yang empirik (sensual), melainkan mencakup fenomena yang tidak lain daripada persepsi, pemikiran, kemauan, dan keyakinan subjek yang dalam penelitian ini adalah elit agama di FKUB Sumatera Utara tentang sesuatu yang di luar subjek yaitu pola kerukunan antar umat beragama. Sedangkan interpretif yang dimaksudkan di sini adalah paradigma yang lebih menekankan pada makna atau interpretasi seseorang atau sejumlah orang, yakni elit agama FKUB Sumatera Utara terhadap wacana-wacana berkembang terkait kerukunan beragama antara kerukunan berdasarkan pluralisme agama atau non-pluralisme agama. Tugas peneliti dalam paradigma ini adalah memaknai (to interpret atau to understand) pendapat atau pemahaman mereka tentang hal tersebut. ${ }^{2}$

Secara garis besar, penelitian ini dilaksanakan dalam 3 (tiga) tahapan inti, yakni tahap orientasi, tahap eksplorasi, dan tahap interpretasi. Sedang teknik yang digunakan dalam pengumpulan data pada penelitian kualitatif ini diprioritaskan pada FGD (Focus Group Discussion). ${ }^{3}$ Teknik ini digunakan dalam rangka mencari dan mendapatkan pemahaman tentang fenomena yang diteliti dari sudut pandang subjek yang diteliti secara utuh, yang dalam hal ini adalah elit agama FKUB Sumatera Utara, hingga akhirnya pemahaman kolektif tersebut dapat dimaknai secara komprehensif, sekalipun dalam FGD juga dimasukkan interview pribadi.

Mengingat bahwa penelitian ini adalah penelitian kualitatif berjenis phenomenologicinterpretif, dimana pemaknaan fenomena yang akan diungkap adalah pemaknaan intersubjektif, FGD di sini juga dipakai sebagai alat analisis untuk mengungkap makna (essence) dari fenomena yang dimaksud, yakni pola kerukunan umat dalam kerangka pluralisme agama atau non-pluralisme agama.

\section{Pola Kerukunan dalam Tataran Elit Agama}

Sebagaimana telah dijelaskan di awal bahwa pada tataran elit di Indonesia, setidaknya ada dua pola yang berkembang, yaitu: pluralisme agama dan non-pluralisme Agama. Namun sebelumnya akan dijelaskan terlebih dahulu makna kerukunan antar umat beragama dalam perspektif UU dan agama-agama.

\section{Makna Kerukunan Umat Beragama}

Istilah kerukunan, sebagaimana disebut Imam Syaukani, berasal dari kata "rukun" berarti: baik dan damai, tidak bertentangan; bersatu hati, bersepakat. Merukunkan berarti:

${ }^{2}$ Noeng Muhajir, Metodologi Penelitian Kualitatif (Yogyakarta, 2002), h. 119.

${ }^{3}$ Burhan Bungin, Analisa Data Penelitian Kualitatif: Pemahaman Filosofis dan Metodologis ke Arah Penguasaan Model Aplikasi (Jakarta: RajaGrafindo Persada, 2003), h. 131. 
mendamaikan; menjadikan bersatu hati. Kerukunan adalah perihal hidup rukun; rasa rukun; kesepakatan: kerukunan hidup bersama. Jadi, kerukunan umat beragama adalah kondisi damai, bersatu hati, atau bersepakat antar pemeluk agama. ${ }^{4}$

Menurut PBM No. 9 dan 8 tahun 2006, Bab 1, Pasal 1, kerukunan umat adalah: ....keadaan hubungan sesama umat beragama yang dilandasi toleransi, saling mengerti, saling menghormati, menghargai kesetaraan dalam pengamalan ajaran agamanya dan kerja sama dalam kehidupan bermasyarakat, berbangsa dan bernegara di dalam Negara Kesatuan Republik Indonesia berdasarkan Pancasila dan Undang-Undang Dasar Republik Indonesia tahun 1945. Bahkan Pemerintah mengembangkan kebijakan trilogi kerukunan, yaitu kerukunan intern umat beragama, kerukunan antarumat beragama, dan kerukunan antar umat beragama dengan pemerintah. ${ }^{5}$

Agama-agama resmi di Indonesia, sebagai subjek dan objek kerukunan, tentunya memiliki pandangan masing-masing tentang kerukunan yang diisyaratkan dari ajarannya masing-masing. Dalam Islam, diperintahkan untuk tidak memaksakan orang lain berpindah agama, ${ }^{6}$ juga diperintahkan untuk mengajak orang dalam kebenaran dengan cara yang beradab. ${ }^{7}$ Lebih dari itu semua, seorang Muslim juga disuruh untuk berbuat adil kepada seluruh manusia walau non-Muslim sekalipun dengan syarat ia tidak memerangi Islam (Q.S. al-Mumtahanah/60: 8-9). Dalam Kristen, umatnya diajarkan untuk hidup rukun antar umat beragama, sebagaimana diucapkan oleh Paulus: "Janganlah membalas kejahatan dengan kejahatan, lakukanlah apa yang baik bagi orang lain" (Roma: 12: 17). Hal senada juga telah diucapkan oleh Yesus: "Segala sesuatu yang kamu kehendaki supaya orang berbuat kepadamu, perbuatlah juga demikian kepada mereka" (Matius: 7: 12). Juga dikatakan: Kasihanilah sesamamu manusia seperti dirimu sendiri (Matius: 22: 39). Di Hindu terdapat ajaran Tri Hita Karana. Tri artinya tiga, Hita artinya sejahtera, selamat, rukun, tentram, harmonis. Sementara Karana artinya, pernyebab Hita, yaitu (Pawongan: hubungan yang harmonis antara manusia dan manusia; Palemahan: hubungan yang harmonis antara manusia dengan alam Parhyangan: hubungan yang harmonis antara manusia dengan Tuhan). Selanjutnya, dalam agama Buddha terdapat enam Dharma yang mengarahkan seseorang untuk saling mengingat, saling mencintai, saling menghormati, dan saling menolong. Di Konghucu, di antara ayat yang mengisyaratkan tentang kerukunan adalah: "seorang susilawan ingin tegak, maka ia juga membantu orang lain tegak dan bila ia ingin maju, maka ia juga membantu orang lain maju." "Saudara saling rukun dalam keluarga akan menentramkan hati orang tua." "Sesuatu usaha itu berhasil dikarenakan mendapat banyak

${ }^{4}$ Imam Syaukani, Kompilasi Kebijakan dan Peraturan Perundang-Undangan Kerukunan Umat Beragama (Jakarta: Puslitbang, 2008), h. 5.

${ }^{5}$ AR. Harahap (ed.), Ensiklopedi Praktis Kerukunan Umat Beragama (Medan: Perdana Publishing, 2005), h. 236-238.

${ }^{6}$ Q.S. al-Baqarah/2: 256.

${ }^{7}$ Q.S. al-Nahl/16: 125 . 
dukungan, sebaliknya gagal dikarenakan kurang mendapat dukungan, dan tiga faktor penentu suatu keberhasilan adalah Tian Se (Kesempatan dan waktu yang tepat)". Ayatayat ini mengajarkan bahwa tidak egois adalah faktor yang membangun kerukunan, sebab kerukunan itu adalah sumber daya manusia.

Pandangan-pandangan di atas menunjukkan bahwa agama-agama dalam idealitanya sangat menunjung tinggi toleransi baik internal umat beragama maupun antar umat beragama. Ini menunjukkan bahwa pada hakikatnya agama-agama tidak ada yang mengajarkan kekerasan (violence), karena sudah fitrah manusia menginginkan hidup damai dan rukun.

\section{Pluralisme Agama}

Secara etimologi pluralisme agama berasal dari dua kata, yaitu: pluralisme dan agama. Kata Pluralism berasal dari kata plural yang artinya jamak, lebih dari satu (more than one). ${ }^{8}$ Dari berbagai kamus pluralism dapat disederhanakan ke dalam dua pengertian. Pertama, pengakuan terhadap keragaman kelompok, baik yang bercorak ras, agama, suku, aliran, maupun partai dengan tetap menjunjung tinggi aspek-aspek perbedaan yang sangat karakteristik di antara kelompok-kelompok tersebut (the existence within society of diverse groups, as in religion, race, or ethnic origin, which contribute to the cultural matrix of the society while retaining their distinctive characters). Kedua, doktrin yang memandang bahwa tidak ada pendapat yang benar atau semua pendapat adalah sama benarnya (No view is true, or that all view are equally true). ${ }^{9}$

Istilah pluralisme, sebagaimana laporan Akbar S. Ahmed sebenarnya sangat terkait dengan pemikiran Barat Posmodern.

To approach an understanding of the postmodernist age is to presuppose a questioning of, a loss of faith in, the project of modernity; a spirit of pluralism; a heightened scepticism of traditional orthodoxies; and finally a rejection of a view of theworld as a universal totality, of the expectation of final solutions and complete answers. ${ }^{10}$

Uraian di atas menunjukkan bahwa pluralisme yang hidup dalam semangat posmodernisme mengajarkan relativisme. Ketika disandingkan dengan agama, pluralisme menjadi sebuah istilah yang disebut pluralisme agama (religious pluralism). Istilah ini (pluralisme agama) telah menjadi terminologi khusus yang sudah baku (technical term), sebagaimana didefinisikan oleh John Hick:

${ }^{8}$ A.S Hornby, Oxford Advanced Leaner's Dictionary of Corrent English (London: Oxford University Press, 1983), h. 889.

${ }^{9}$ The New International Webster's Comprehensive Dictionary of the English Language (Chicago: Trident Press International, 1996), h. 972; Simon Blackburn, Oxford Dictionary of Philosophy (Oxford: Oxford University Press); Lorens Bagus, Kamus Filsafat (Jakarta: Gramedia, t.t.), h. 855.

${ }^{10} \mathrm{Akbar}$ S. Ahmed, Postmodernism and Islam: Predicament and Promise (London and New York: Routledege, 1992), h. 10. 
..pluralism is the view that the great world faiths embody different perceptions and conceptions of, and correspondengly different responses to, the real or the Ultimate from within the major variant cultural ways of being human; and that within each of them the transformation of human existence from self-centredness to Reality centredness is manifestly taking place and taking place, so far as human observation can tell to much the same extent [pluralisme agama adalah suatu gagasan bahwa agama-agama besar dunia merupakan persepsi dan konsepsi yang berbeda tentang Yang Real atau Yang Maha Agung dari kultur manusia yang bervariasi; dan bahwa transformasi wujud manusia dari pemusatan-diri menuju pemusatan-Hakikat terjadi secara nyata dalam kultur manusia tersebut dan terjadi, sejauh yang dapat diamati, sampai pada batas yang sama].

Menurut Nurcholis Madjid, bahwa ada tiga sikap dialog agama yang dapat diambil. Pertama, sikap eksklusif, yang memandang bahwa agamanya yang paling benar dan yang lain sesat. Kedua, sikap inklusif yang memandang bahwa agama-agama lain adalah bentuk implisit dari agamanya. Ketiga, sikap pluralis, yang memandang agama-agama sama dengan agamanya dan sama-samah jalan yang sah dalam mencapai kebenaran.

MUI dalam fatwanya tahun 2005, juga mempertegas bahwa "pluralisme agama adalah suatu paham yang mengajarkan bahwa semua agama adalah sama dan karenanya kebenaran setiap agama adalah relatif. Sebab itu, "setiap pemeluk agama tidak boleh mengklaim bahwa hanya agamanya saja yang benar sedangkan agama yang lain salah. Pluralisme agama juga mengajarkan bahwa semua pemeluk agama akan masuk dan hidup berdampingan di surga."11

Di Indonesia, paham pluralisme agama setidaknya merujuk pada dua aliran. Pertama, teologi global (Global Theology) lahir dari rahim globalisme Barat. Pengusungnya adalah John Hick seorang teolog Kristen Protestan. ${ }^{12}$ Dalam teorinya, Hick merumuskan sebuah revolusi teologis dari pemusatan agama-agama menuju pemusatan tuhan (the transformation from religion-centredness to God-centerdness). Selain itu, Hick juga memandang bahwa agama-agama adalah realitas dari tanggapan budaya manusia yang berbeda-beda dari Satu Yang Nyata (The Real). ${ }^{13}$ Dengan teorinya ini, Hick ingin menegaskan bahwa kebenaran agama tidaklah monolitik atau tunggal tapi bersifat plural sesuai dengan jumlah tradisitradisi atau ajaran-ajaran agama yang melaluinya manusia melakukan respons terhadapnya. ${ }^{14}$

\footnotetext{
${ }^{11}$ Lihat Fatwa MUI No: 7/Munas/VII/MUI/II/2005 tentang Pluralisme, Liberalisme dan Sekulerisme Agama.

${ }^{12}$ Akibat globalisme membuat agama-agama berkoeksistensi antara satu dengan yang lain, Hick mengajukan teologi global sebagai solusi yang kompetibel dengan memodfikasi klaim eksklusivisme dan inklusivisme agama-agama, Lihat Adnan Aslan, Religious Pluralism in Christian and Islamic Philosophy: the Though of John Hick and Seyyed Hossein Nasr (t.t.p.: Curzon Press, 1998), h. 99.

${ }^{13}$ John Hick, Tuhan Punya Banyak Nama, terj. Amin Ma'ruf dan Taufik Aminuddin (Jakarta: Interfidei, 2006), h. 65.

${ }^{14}$ Lebih jelasnya, baca Anis Malik Thoha, Tren Pluralisme Agama: Tinjauan Kritis (Jakarta: Perspektif, 2007), h. 83.
} 
Kedua, kesatuan transenden agama-agama (Transcendent Unity of Religion) lahir sebagai kritik terhadap globalisme dan modernitas Barat yang anti agama. Pengusungnya yang terkenal adalah Fritchof Schuon. Ia membagi agama-agama kepada dua hakikat; eksoterik (lahiriah), dan esoterik (batiniah). Dari sudut pandang ini, agama-agama seperti Islam, Kristen, Yahudi, Hindu, dan Buddha merupakan bentuk lahiriah (eksoterik) yang dipisahkan oleh garis horizontal dan bertemu pada hakikat esoterik. ${ }^{15}$

Sejatinya, pandangan ini ingin mengantarkan manusia kepada sebuah kesepakatan pandangan bahwa semua agama merupakan manifestasi-manifestasi dan bentuk-bentuk yang beragam dari hakikat esoterik yang tunggal. Dari sudut pandang ini dimensi esoterik merupakan sesuatu yang absolut dan dimensi eksoterik bersifat relatif agar agama-agama dapat berkoeksistensi satu sama lainnya. ${ }^{16}$

\section{Non-Pluralisme Agama}

Pola ini mengakui bahwa keragaman atau pluralitas adalah sebuah keniscayaan yang tidak dapat ditolak, namun tidak mengakui bahwa semua agama itu sama. Sebab, dalam agama-agama terdapat klaim teologis yang tidak bisa diganggu gugat. Seluruh agama boleh mengakui kesalahan teologi agama yang lain, tetapi hal itu tidak berarti boleh memaksakan orang yang beragama lain masuk ke agama yang dianut, serta membiarkan mereka untuk melaksanakan ajaran-ajarannya masing-masing dengan aturan-aturan yang telah disepakati bersama di Negara Kesatuan Republik Indonesia. Biasanya paham ini diusung oleh sebagian besar para pemuka Agama, bahkan MUI tahun 2005 telah mengeluarkan fatwa atas keharaman Pluralisme Agama.

Dari sejumlah karya yang mengusung pola kerukunan dalam bingkai non-pluralisme, setidaknya dapat disarikan bahwa pola kerukunan mereka berdiri di atas hal-hal sebagai berikut. Pertama, mengakui kemajemukan agama namun tidak membenarkannya. Hal itu karena adanya perbedaan fundamental secara teologis agama-agama. Islam adalah agama tauhid yang mengakui Allah sebagai Tuhan, sedangkan Yahudi mengakui Yahweh sebagai tuhan khusus bagi golongan mereka; Kristen mengakui satu Tuhan tapi memiliki tiga unsur (Tuhan Bapak, Tuhan Anak, dan Ruh Kudus), atau dikenal dengan Trinitas. Sedangkan agama-agama non-semitik seperti Hindu, Majusi, dan Taoisme beriman pada banyak Tuhan atau disebut politeistik. Kedua, mentolerir kebebasan beragama dalam memeluk dan melaksanakan ibadah menurut ajaran masing-masing, namun ini bukan berarti menghilangkan dakwah atau mengajak kepada kebaikan, dan mentolerir setiap aliran sempalan yang sesat dan menyesatkan. Ketiga, kesatuan non-teologis tapi sosiologis. Walaupun secara teologis tidak dapat bersatu, namun pemeluk agama dapat bekerjasama

\footnotetext{
${ }^{15}$ Lihat gambaran Huston Smith, dalam pengantar buku Frithjof Schuon, The Transcendent Unity of Religions (London: Quest Book Theosopical Publishing House, 1993), h. xii.

${ }^{16}$ Lebih jelasnya, Thoha, Tren Pluralisme Agama, h. 117-118.
} 
dalam ranah sosial seperti mengadakan gotong royong bersama, dan kegiatan-kegiatan sosial lainnya. Keempat, aturan penyiaran agama dan pembangunan rumah ibadah. Ini merujuk pada PBM No. 9 dan 8 tahun 2006. Kelima, mematuhi peraturan keagamaan baik dalam agamanya maupun peraturan Negara atau Pemerintah.

\section{Hasil dan Pembahasan}

Dari hasil wawancara peneliti melalui FGD terhadap beberapa elit agama di FKUB Sumatera Utara, dapat disarikan beberapa poin penting mengenai posisi mereka terhadap dua pola kerukunan yang berkembang di tataran elit. Selain itu juga ditemukan beberapa langkah-langkah teknis kerukunan FKUB Sumatera Utara, untuk kemudian dianalisis kesesuaian antara posisi atau idealita yang dibangun dengan realitas di lapangan. Namun, sebelum lebih jauh pada hal-hal sebagaimana disebutkan, berikut akan dipaparkan sekilas tentang FKUB Sumatera Utara.

\section{Sejarah FKUB Sumatera Utara}

Pembentukan FKUB Sumatera Utara dapat dilihat dari dua tahapan. Pertama, prapembentukan. Di wilayah Sumatera Utara, sebelum terbentuk FKUB, sudah ada forum komunikasi pemuka antar agama (FKPA) yang terbentuk tahun 1996. Pembentukan tersebut didukung oleh tiga pilar utama, yaitu tokoh agama (Toga), Forum Komunikasi Antar Lintas Budaya (Forkala), dam forum pemuda. Karena itu, setelah dikeluarkan PBM sebagaimana disebutkan, Kepala Kanwil Depag Sumatera Utara meminta kepada Gubernur Sumatera Utara untuk segera membentuk FKUB di provinsi Sumatera Utara melalui surat tanggal 6 Juli 2006 — dengan mengundang pengurus FKPA Sumatera Utara dan pemimpin majelis-majelis agama serta instansi terkait. Menindaklanjuti hal itu, Pemerintah Provinisi mengundang utusan dari majelis-majelis Agama yang ada untuk merumuskan dan menyepakati Peraturan Gubernur (Pergub) tersebut. Setelah dicapai kesepakatan, Kepala Kantor Wilayah Depag Sumatera Utara menyurati Majelis-Majelis Agama untuk merekomendasikan utusannya yang akan duduk di FKUB dengan komposisi sesuai amanat PBM dan Pergub Sumatera Utara. ${ }^{17}$

Kedua, tahap pembentukan. Pada akhir tahun 2006, Gubernur Sumatera Utara menerbitkan surat keputusan No. 24 tahun 2006 tanggal 19 Desember 2006 tentang FKUB dan Dewan FKUB provinsi dan Kabupaten/Kota. Isi keputusan itu antara lain ketentuan tentang pembentukan FKUB dan Dewan Penasihat FKUB, tugas dan fungsinya, jumlah, komposisi dan keanggotaan, kepengurusan, hubungan kerja, biaya, pengembangan FKUB, pengawasan, dan pelaporan. Pada tanggal 21 Februari 2007, diadakan rapat musyawarah yang menghasilkan kesepakatan tentang pembentukan FKUB dengan posisi keanggotaan ber-

${ }^{17}$ Data ini diperoleh dari dokumen FKUB Sumatera Utara. 
dasarkan perbandingan jumlah pemeluk agama dengan keterwakilan minimal 1 orang dari tiap agama. Berdasarkan sensus Badan Pusat Statistik (BPS) tahun 2000 terhadap jumlah penganut agama di Sumatera Utara, maka komposisi FKUB yang disepakati adalah: Islam 11 orang, Kristen 5 orang, Katolik 2 orang, Buddha, Hindu dan Konghucu masing-masing 1 orang. ${ }^{18}$

Pada periode saat ini yaitu 2012-2017, susunan FKUB Sumatera Utara adalah: ${ }^{19}$

$\begin{array}{ll}\text { Ketua } & \text { : Dr. H. Maratua Simanjuntak } \\ \text { Wakil Ketua } & \text { : Pastor Benno Ola Tage Pr, Oemar Witaryo } \\ \text { Sekretaris } & \text { : Pdt. Dr. Elim Simamora, D. Th } \\ \text { Bendahil Sekretaris } & \text { : Dr. H. Arifinsyah, M. Ag., Naran Sami, SH } \\ \text { Wakil Bendahara } & \text { : Andi Wiranata, SE } \\ \text { Anggota } & \text { : Drs. Sarwo Edi, MA } \\ & \text { : Prof. Dr. Hasan Bakti Nasution } \\ & \text { Drs. H. Ansari Yamamah, MA } \\ & \text { Drs. H. M. Arifin Umar, } \\ & \text { Drs. Abd Razak, M. Si, } \\ & \text { Najamuddin, MA, } \\ & \text { Nisful Khoiri, MA, } \\ & \text { Darma Efendy, MM, } \\ & \text { Bishop Dr. John Hasiholan Manurung, WTP. } \\ & \text { Simarmata, M. Th, } \\ & \text { Pdt. Enida Girsang, M. Th, Pdt. } \\ & \text { Drs. J. Washington Panjaitan, S.Th, } \\ & \text { Drs. Albert Pakpahan, M.Si }\end{array}$

Adapun Visi FKUB Sumatera Utara adalah: "Menjadikan kerukunan beragama sebagai suatu kebutuhan dalam pemberhasilan pembangunan untuk mencapai kesejahteraan dunia dan akhirat". Sedangkan misinya adalah sebagai berikut. Pertama, melakukan komunikasi, konsultan dan mediasi pembinaan kerukunan hidup umat beragama. Kedua, melakukan dialog, sosialisasi dan edukasi tentang kerukunan hidup umat beragama. Ketiga, memberikan motivasi dan implementasi dalam pelaksanaan kerukunan hidup beragama untuk kesejahteraan dunia dan akhirat. Keempat, memberdayakan masyarakat dan lembaga jejaring kerukunan sebagai objek dan subjek dalam memelihara dan meningkatkan kerukunan. Adapun tujuannya: ${ }^{20}$ Pertama, memfasilitasi terciptanya kerukunan

\footnotetext{
${ }^{18}$ Arifinsyah, FKUB dan Resolusi Konflik, h. 52.

${ }^{19}$ Ibid., h. 55.

${ }^{20}$ Elin Simamora, et al. Refleksi Forum Kerukunan Umat Beragama Provinsi Sumatera Utara sebagai Evaluasi Menuju Penyempurnaan Eksistensi (Medan: FKUB-SU, 2013), h. 12-13.
} 
dan keharmonisan antar umat beragama di Sumatera Utara. Kedua, untuk memlihara kerukunan antar umat beragama ke arah persatuan dan kesatuan, serta untuk keutuhan berbangsa dan bernegara. Ketiga, untuk meningkatkan pemahamaan keberagamaan ke arah saling menghormati dan menghargai antarumat beragama yang ada di Sumatera Utara. Keempat, menampung aspirasi umat beragama dalam penyelesaian masalah yang terjadi di tengah masyarakat.

\section{Pola Kerukunan Perspektif FKUB Sumatera Utara Pluralitas adalah Kehendak Tuhan}

Pluralitas atau keragaman merupakan kehendak Tuhan yang tidak dapat diganggu gugat. Hal ini juga disadari oleh FKUB Sumatera Utara, bahwa manusia secara ontologis diciptakan berbeda-beda, baik suku, bahasa, warna kulit, kepercayaan agama dan lain sebagainya. Perbedaan adalah kehendak yang maha kuasa, dan manusia tidak akan mampu mengubahnya. Karena perbedaan tersebutlah putih bisa disebut putih, Batak bisa disebut Batak, begitulah perbedaan yang satu dengan yang lainnya dan secara alami memberikan identitas pada masing-masing. Bapak Arifinsyah, tokoh Muslim di FKUB menuturkan: ${ }^{21}$

...Tuhan sendiri sudah bilang dalam surat Hû̂d/11: 118, "jikalau Tuhanmu menghendaki, tentu dia menjadikan manusia umat yang satu, tetapi mereka senantiasa berselisih pendapat." Ini artinya berbeda itu adalah kehendak Tuhan, maka jangan dipaksakan seseorang untuk sama...tapi jangan salah tafsir anda...walaupun pada hakikatnya manusia berbeda...ini bukan berarti kita menjustifikasi kesesatan.

Pandangan di atas juga diamini oleh tokoh lainnnya. Jika dianalisis, pengakuan terhadap pluralitas oleh FKUB Sumatera Utara berpijak pada distingsi kehendak Tuhan secara ontologis dan epistemologis. Yang pertama merujuk pada kesadaran bahwa pada hakikatnya perbedaan merupakan eksistensi kehidupan yang berfungsi sebagai keseimbangan; ada baik dan buruk, cahaya dan gelap, laki-laki dan perempuan, dan lain sebagainya. Yang kedua merujuk pada hakikat manusia sebagai makhluk rasional yang dapat membedakan antara baik dan buruk; hak dan batil. Kekuatan akal menjadi legislator bagi dirinya untuk dapat memilah dan memilih yang terbaik bagi dirinya. ${ }^{22}$

Dalam konteks Indonesia, kesadaran sebagaimana dijelaskan wujud dalam semboyan bangsa: Bhinneka Tunggal Ika, berbeda-beda tetapi satu juga. Menurut FKUB Sumatera Utara, apa yang terkandung dalam semboyan tersebut menumbuhkan kesadaran bahwa masyarakat yang majemuk, namun tetap satu dalam bingkai Indonesia. Namun demikian, kemajemukan

\footnotetext{
${ }^{21}$ Focus Group Discussion (FGD), 22 Maret 2017 di Fakultas Ushuluddin UIN Sumatera Utara Medan.

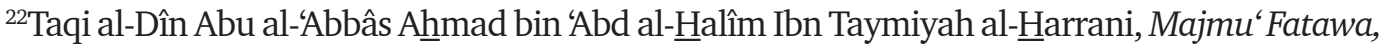
Juz 18 (Beirut: Dâr al-Wafa', 1426 H), h. 134.
} 
tersebut tidak serta merta mentolerir bentuk penistaan. Aturan pemerintah seperti dalam kitab undang-undang hukum pidana pasal 156a dan pasal 169 serta Undang-Undang No.1 PNPS/ 1965 tentang Pencegahan Penyalahgunaan dan atau Penodaan Agama-menunjukkan bahwa semboyan Bhinneka Tunggal Ika tidak mentolerir sikap beragama yang menyakiti perasaan penganut agama lain.

\section{Kerukunan adalah Menghargai Pluralitas, bukan Pluralisme}

Menurut FKUB Sumatera Utara, kerukunan adalah hidup damai antar pemeluk agama yang dilandasi toleransi, saling menghargai, sebagaimana telah dijelaskan dalam PBM No. 9 dan 8 tahun 2006, Bab 1, Pasal 1. Namun perlu dicatat bahwa sikap toleran, dan saling menghargai tersebut, bukanlah pada tataran teologis, melainkan hanya pada tataran sosiologis. Ini artinya, seseorang tidaklah boleh di satu sisi meyakini agamanya benar, dan di sisi lain juga mengakui agama yang lain juga benar. Hal ini sebagaimana dituturkan oleh Bapak Arifinsyah, selaku sekretaris FKUB Sumatera Utara: ${ }^{23}$

Rukun itu ya saling menghargai, tapi ingat...rukun yang kami maksud bukan seperti penafsiran orang-orang sekuler liberal yang bilang bahwa untuk hidup rukun setiap insan-insan beragama jangan anggap agama yang paling benar, dan yang lain sesat... itu tidak betul itu. Keyakinan seperti ini bisa merusak...masyarakat akan kacau... karena setiap agama punya kepercayaan dan ajarannya masing-masing, jadi tidak boleh disamasamakan.

Hal senada juga diungkap oleh bapak Albert Pakpahan: ${ }^{24}$

Rukun itu adalah orang lain tentram dengan keberadaan kita, tapi tidak melampaui sekat-sekat teologis yang sudah jadi keyakinan Pakem penganut-penganut agama. Ngaku agamanya yang paling benar itu wajar ko'...tapi ingat keyakinan kita jangan dipaksakan ke orang lain...jadi wajar orang Islam meyakini yang Kristiani kafir, kami bilang yang selain kami domba-domba tersesat...itu wajar...asal keyakinan itu jangan didengung-dengungkan dengan orang lain.

Lebih jauh, menurut FKUB, memaknai kerukunan sebagaimana mereka sebutkan merupakan logika sehat dan memiliki landasan teologis yang tetap dari agama-agama. Dalam timbangan logis, menurut mereka mustahil bagi akal menerima pemaknaan kerukunan dalam bingkai mengakui kebenaran agama-agama lain atau sering diistilahkan sebagai pluralisme. Terkait ini, Bapak Arifinsyah menuturkan:

Bahwa pluralisme adalah istilah teknis (technical term) yang berasal dari tradisi Barat, yang trauma menghadapi realitas keberagamaan mereka. Pola ini baik secara akal dan teologis juga tidak bisa diterima. Kita, dalam konteks Indonesia, khususnya Sumatera Utara, tidak perlu pola yang demikian, kalau hanya sekadar ingin rukun. MUI sendiri

\footnotetext{
${ }^{23}$ Focus Group Discussion (FGD), 22 Maret 2017.

${ }^{24}$ Ibid.
} 
sudah mengecam pola yang demikian. Bahkan pemuka-pemuka agama di Indonesia banyak yang mengecam sampe-sampe menulis buku untuk mengkritisinya.

Senada dengan itu, peneliti LIPI dalam sosial keagamaan bapak Shiyamu Manurung juga menuturkan bahwa pluralisme adalah kerukunan semu, yang justru akan merusak makna kerukunan itu sendiri, kerukunan bukanlah menyama-nyamakan, namun dapat berlapang dada dalam perbedaan. ${ }^{25}$

Jika dianalisis, pernyataan elit FKUB di atas selaras dengan agamawan yang menolak pluralisme agama. Dari teolog Kristen, Frans Magnis Suseno menilai bahwa tawaran toleransi yang ada pada pluralisme agama adalah sebuah sikap yang menghina meskipun bermaksud baik. Baginya toleransi bukanlah asimilasi agama, melainkan format penuh identitas masingmasing yang tidak sama. Senada dengan itu, Pdt. Stevri Lumintang menyatakan bahwa pluralisme agama adalah suatu tantangan sekaligus bahaya yang sangat serius bagi kekristenan. ${ }^{26}$ Poltak YP Sibarani dan Benard Jody A Siregar dalam Beriman dan Berilmu: Panduan Kristen Pendidikan Agama Kristen untuk Mahasiswa, menjelaskan bahwa pluralisme bukan sekadar menghargai fakta pluralitas agama. Akan tetapi, paham tersebut sekaligus menganggap penganut agama lain setara dengan agamanya. Ini adalah sikap untuk menerima dan menghargai agama lain sebagai agama yang baik dan benar, serta mengakui adanya jalan keselamatan di dalam agama-agama selain yang diyakininya. ${ }^{27}$

Ngakan Made Madrasuta menulis bahwa..."pandangan bahwa semua agama sama telah melawan pendekatan pluralistik dari tradisi Hindu. Menjadikan semua agama sama adalah suatu penolakan atas pluralisme dan dapat melahirkan bentuk lain dari intoleransi. ${ }^{28}$ Dalam Islam, MUI melalui fatwanya sebagaimana disebutkan sebelumnya, juga telah menyatakan bahwa paham pluralisme agama bertentangan dengan Islam, dan haram bagi umat Islam memeluk paham ini. Anis Malik Thoha, pakar pluralisme agama, yang juga Mustasyar NU cabang Istimewa Malaysia, menyimpulkan bahwa pluralisme agama adalah sebuah paham yang sangat destruktif terhadap Islam dan agama-agama lain. Hal itu disebabkan adanya kesalahan dalam memandang agama baik secara metodologis, epistemologis dan aksiologis: ${ }^{29}$

Secara metodologis, pandangan di atas melakukan pendekatan terhadap agama secara reduksionistik, yakni memahami agama hanya sebatas respon manusia (human respons). Berarti menafikan agama sebagai sesuatu yang datang dari Tuhan. Kalau dikatakan demikian maka agama-agama semuanya sama, tidak ada yang superior antara satu dengan yang lainnya. Selain itu, pandangan ini juga memaksa agama untuk melepaskan doktrin

${ }^{25}$ Ibid.

${ }^{26}$ Stervri Lumintang, Teologi Abu-Abu (Pluralisme Iman) (Malang: YPPII, 2002), h. 15.

${ }^{27}$ Poltak YP Sibarani \& Bernard Jody A. Siregar, Beriman dan Berilmu: Panduan Kristen Pendidikan Agama Kristen untuk Mahasiswa Ramos (Jakarta: Gospel Publishing House, 2005), h. 126.

${ }^{28}$ Ngakan Made Madrasuta (ed.), Semua Agama tidak Sama (Medan: Media Hindu, 2006).

${ }^{29}$ Lebih lengkapnya baca Thaha, Tren Pluralisme Agama, h. 123-141. 
klaim kebenarannya (truth claim) agar dapat berinteraksi dalam ruang sosial. Dalam pluralisme terselubung sekularisasi yang memisahkan urusan agama dengan sosial. Tentunya hal itu menghilangkan absolutisme agama dan menjadikan manusia berada pada garis skeptis terhadap keyakinannya sendiri dalam beragama.

Secara epistemologis, pandangan di atas seakan lebih paham akan agama-agama daripada penganutnya. Hal ini dapat dilihat dari konsepsi mereka tentang agama yang bersifat relatif. Itu tentunya tampak bias alias paradoks karena di satu sisi mereka merelatifkan agama-agama namun pada sisi lain mereka mengabsolutkan pandangan mereka tentang Yang Nyata, dan hakikat Esoterik, yang itu tentunya bertentangan tentang konsepsi agamawan (Islam, Kristen, dan Yahudi) tentang Tuhan mereka. Kalaulah pluralisme agama konsisten dengan kerelatifannya atas agama-agama, maka pluralisme agama adalah relatif, lalu mengapa memaksakan agar agama-agama berpandangan demikian?

Secara aksiologis, penilaian pluralisme agama terhadap agama-agama adalah bias dari lensa subjektifnya, karena menganggap agama-agama relative, namun mengabsolutkan pandangannya. Sebenarnya apabila ditelisik pandangan ini ingin merevolusi doktrin teologis agama-agama, dan pada akhirnya agama-agama akan kehilangan jati dirinya.

Dari pemaparan elit-elit agama di atas, dapat disimpulkan bahwa pola kerukunan pluralisme agama sangat problematis. Problematika tersebut juga telah disadari oleh FKUB Sumatera Utara yang tidak menerima jika agama pada hakikatnya semua sama.

\section{Kerukunan adalah Bekerjasama dalam Kemasyarakatan dan Kebangsaan}

Secara kodrati, manusia adalah makhluk sosial atau makhluk yang bermasyarakat. Dalam artian, manusia selalu hidup bersama di antara manusia lainnya. Pada konteks yang demikian, manusia dituntut untuk dapat bekerjasama. Karena itu, walaupun secara teologis memiliki klaim kebenaran masing-masing, namun sebagai masyarakat dan bangsa yang majemuk, seseorang haruslah dapat bekerjasama dalam kehidupan bermasyarakat. Lebih jauh, Bapak Sarwo Edi, selaku bendahara FKUB menuturkan:

Ya, kita memang punya keyakinan yang beda-beda, tapi harus ingat bahwa kita ini semua saudara di bawah payung kemanusiaan, kemasyarakatan, kebangsaan dan lain sebagainya itu...perbedaan adalah kehendak Tuhan...kita adalah makhluk sosial... yang dalam kehidupan sehari-hari tentunya butuh pertolongan orang lain untuk memenuhi kebutuhan sehari-hari kita...makanya harus bisa kerjasama...ada hal-hal yang kita bisa sama dalam kerja-kerja yang sifatnya sosial.

Pendapat senada juga diungkap oleh Bapak Arifinsyah. Baginya, bangsa Indonesia dengan semboyan "Bhineka Tunggal Ika" berbeda-beda tetap satu jua, adalah landasan yang mendasari untuk senantiasa merajut kerjasama antar sesama walaupun berbeda keyakinan. Lebih jauh ia menuturkan: ${ }^{30}$

${ }^{30}$ Focus Group Discussion (FGD), 22 Maret 2017. 
Agama-agama di dunia juga mengajarkan berbuat baik kepada sesama manusia. Dalam ajaran Islam misalnya, kita diperintahkan berbuat baik kepada non-Muslim. Apa yang kami konsepsikan saat ini juga ada fakta sejarahnya di zaman Nabi. Pada waktu itu Nabi mengakomodir kerukunan antar umat beragama...bahkan Nabi sendiri menghormati jenazah Yahudi yang lewat...dengan berdiri...karena ia adalah manusia.

Lebih jauh, Bapak Shiyamu menambahkan bahwa kerjasama tersebut harus dibentuk dengan lima hal berikut. Pertama, motif-motif suci dalam rangka pengabdian kepada Tuhan, yaitu kerjasama yang dilandaskan oleh nilai kesucian, kebenaran, dan kebaikan dalam rangka mencapai keselamatan dan kesejahteraan berbangsa. Kedua, rasa persahabatan, kekeluargaan, persaudaraan dan rasa sepenanggungan. Ketiga, mengarah pada pengembangan nilai-nilai dinamik yang direpresentasikan dengan suasana yang interaktif, bergerak, bersemangat, dan bergairah dalam mengembangkan nilai kepedulian, keaktifan, dan kebajikan bersama. Keempat, berorientasi pada penngembangan suasana kreatif. Kelima, mengarah pada pengembangan nilai produktivitas umat, dan nilai-nilai sosial praktis dalam upaya mengentaskan kemiskinan, kebodohan, dan ketertinggalan, seperti mengembangkan amal kebajikan, bakti sosial, badan usaha, dan berbagai kerjasama sosial ekonomi yang mensejahterakan umat. ${ }^{31}$

Dari sini dapat disimpulkan bahwa FKUB Sumatera Utara memiliki pola toleransi non-Pluralisme dalam mengkonsepsikan kerukunan. Pola tersebut memiliki arti bahwa setiap individu memiliki klaim teologisnya masing-masing, namun dalam kemanusiaan seseorang tidak boleh memaksakan keyakinannya kepada orang lain. Lebih dari itu seseorang juga harus mampu bekerjasama dengan yang lain baik dari yang satu keyakinan dan lain keyakinan. Kedua aspek tersebutlah yang mengantarkan kepada sebuah kondisi rukun.

\section{Penerapan Pola Kerukunan FKUB Sumatera Utara}

Dalam lingkup nasional, Sumatera Utara sebagaimana dijelaskan oleh FKUB Sumatera Utara masih menjadi acuan dalam kerukunan antar umat beragama. Hal ini sebagaimana diungkap oleh bapak Arifinsyah:

Hasil pertemuan nasional kita masih barometer walaupun ada kecolongan di Tanjung Balai tapi itu tidak menjadi nilai merah, tetap juga Sumatera Utara menjadi barometer Nasional dalam kerangka pemeliharaan kerukunan.

Namun daripada itu, semenjak terbentuknya hingga sekarang, FKUB Sumatera Utara telah melakukan langkah-langkah sebagai bentuk turunan dari idealita kerukunan sebagaimana dijelaskan sebelumnya.

${ }^{31}$ Ibid. 


\section{Melakukan Dialog Teologis}

Dialog teologis atau interreligious dialogue pada dasarnya bertujuan untuk mengikis rasa permusuhan serta menumbuhkan sikap saling memahami, saling memaklumi dan saling menghormati. Kegiatan semacam ini genjar dilakukan oleh Gereja Katolik semenjak tahun 1988 melalui The Pontificial Council for Interreligious Dialogue (PCID). ${ }^{32}$ Pada konteks FKUB Sumatera Utara, dialog teologis yang dilakukan tidaklah resmi, namun berjalan apa adanya dalam diksusi-diskusi santai dengan para tokoh elit agama. Dialog berlangsung di kantor FKUB sendiri antar sesama mereka sebagai pengurus khususnya tentang konsep Tuhan pada masing-masing agama. Hal ini sebagaimana dituturkan oleh Bapak Sarwo Edi:

...itu di FKUB kita yang tidak dilakukan oleh FKUB lain....di kantor itu dilakukan diskusi tentang teologi...misalnya Tuhan menurut Islam, Tuhan menurut Katolik, Tuhan menurut Hindu dan lain-lain....itu pola satu...jadi berbasis teologis.

Namun, sebagaimana dijelaskan oleh Bapak Arifinsyah bahwa dialog tersebut bukanlah untuk menyama-nyamakan agama tetapi sebagai sarana untuk saling mengenal, dan memperkaya khazanah pengetahuan dalam beragama sehingga dapat saling menghargai, dan tidak saling memperolok-olok antara satu agama dengan agama lainnya. Karena itu, lanjut Bapak Arifinsyah, seseorang yang berdialog haruslah berdiri pada prinsip-prinsip berikut. Pertama, menganggap bahwa status antar sesama mereka tidaklah sama. Kedua, setiap yang berdialog haruslah menganggap keyakinannya yang paling benar dan yang lain sesat atau salah. Ketiga, fokus pada masalah-masalah besar yang menjadi sumber konflik antar umat beragama.

\section{Melakukan Interaksi Sosial}

Maksudnya adalah mencari formula-formula yang dapat merekatkan persaudaraan masyarakat. Namun, formula tersebut tidaklah bersifat teologis namun sosiologis, seperti unsur kearifan lokal atau local wisdom. Hal ini sebagaimana diungkap oleh Bapak Arifinsyah:33

Interaksi sosial yang kita lakukan di masyarakat...itu tidak menyangkut hal-hal yang sakral tapi persoalan-persoalan yang profan...di sinilah banyak unsur-unsur budaya yang masuk...keberuntungan Sumatera Utara dibandingkan yang lain perekatnya itu sebenarnya perekat budaya...sudah kita rasakan...ada satu rumah beda agama tapi satu budaya...rukun. Jadi kalau dia datang yang Muslim...yang Kristen nyiapkan sajadah... itu luar biasa...itu kita temukan di Dairi...di Karo...apalagi di Angkola...Angkola itu ada gak ada FKUB udah dari dulu mereka udah terbiasa hidup berdampingan...Gereja

${ }^{32}$ Kegiatan dialog tersebut merupakan tindak lanjut dari konsili pada tahun 1962-1965 yang menghasilkan dokumen Nostra Aetate, di mana umat Kristiani diperintahkan untuk bersifat inklusif terhadap agama-agama lain, yang sebelumnya sangat eksklusif dan cenderung intoleran. Lihat Syamsuddin Arif, "Interfaith Dialogue dan Hubungan Antraagama dalam Perspektif Islam," dalam Tsaqafah: Jurnal Peradaban Islam, Vol. 6, No. 1, April 2010, h. 148-149.

${ }^{33}$ Ibid. 
ama Masjid itu berdampingan...nanti kebersihannya saling kerjasama...hari minggu ini bersihkan Gereja...Jumat nanti bersihkan Masjid dengan varian-varian heterogen yang ada...jadi luar biasa...itu bukan karena FKUB...itu bangkit dari naluri kebersamaan".

Dalam hal ini, terlihat bahwa FKUB Sumatera Utara sangat menyadari betapa pentingnya kearifan lokal di tengah-tengah masyarakat Sumatera Utara yang multi-etnis. Selain itu, inflitrasi modernitas juga menjadi salah satu alasan penting untuk menghidupkan kembali kearifan lokal suku yang ada di Sumatera Utara.

\section{Penanganan Konflik melalui Advokasi dan Regulasi}

Maksud dari FKUB ini adalah bahwa konflik-konflik yang selama ini muncul di masyarakat bukanlah karena keyakinan akan kebenaran agamanya, melainkan diakibatkan oleh advokasi yang lambat dan adanya pelanggaran atas regulasi yang telah ditetapkan atau ketidakjelasan regulasi itu sendiri. Pelanggaran regulasi ini sebagaimana dituturkan oleh Bapak Arifinsyah mencakup wilayah doktrinasi, yaitu doktrin keagamaan yang dipaksakan; simplifikasi yaitu pandangan yang terlalu sempit terhadap agama, serta misi-misi yang dilakukan oleh agama khususnya Islam dan Kristen yang cenderung melanggar regulasi.

Namun perlu dicatat, bahwa dibandingkan dengan daerah-daerah lain, proses mediasi yang dilakukan oleh FKUB Sumatera Utara dapat digolongkan cepat, dan tidak pernah sampai kepada regulasi pemerintah pusat. Hal ini sebagaimana dipaparkan oleh bapak Sarwo Edi:

Kami ada atau tidak ada dana dari pemerintah daerah, segera turun ke wilayah kalau ada masalah...karena kami sadar bahwa ini masalah kemanusiaan dan tidak bisa dibiarkan berlarut-larut....memang dana termasuk kendala untuk melakukan mediasi... tapi itu tidak masalah....walaupun dari kantong sendiri.

\section{Dialog Interaktif}

Menurut FKUB Sumatera Utara, melakukan dialog secara informal kepada masyarakat terkait kerukunan adalah salah satu hal penting yang perlu dilakukan. Lebih jauh, menurut mereka dialog kerukunan pemerintah pusat saat ini lebih kepada by design, dalam artian bersifat top down yang berujung pada kerukunan semu. Ini sebagaimana dituturkan oleh bapak Arifinsyah: ${ }^{34}$

Ini kami jujur saja dari FKUB, kami itu gak setuju sama kegiatan-kegiatan yang dibuat oleh pemerintah....itu by design aja itu...cenderung ngabisin anggaran...bersifat top down...ini kerukunan semu...di bawah justru ketakutan...inilah kalau dipicu akan mudah pecah...seharusnya kegiatan kerukunan itu harus bottom-up, ya dari masyarakat itu sendiri.

${ }^{34}$ Ibid. 
Selanjutnya, menurut Bapak Shiyamu Manurung, selaku peneliti bahwa apa yang telah dilakukan FKUB Sumatera Utara sangat apresiatif, namun dalam melakukan dialog interaktif sesuai idealita FKUB Sumatera Utara perlu adanya jejaring khususnya ke masyarakat akademik. Hal ini bertujuan agar ada perpanjangan tangan FKUB Sumatera Utara dalam sosialisasi.

Dari sini terlihat bahwa dalam menerapkan idealita kerukunanannya, FKUB Sumatera Utara telah melakukan dua hal berikut. Pertama, pencegahan dengan melakukan dialog-dialog keagamaan di kalangan elit agama, dan dialog-dialog interaktif-sosio kultural dengan memanfaatkan sistem kearifan lokal yang berlaku pada masyarakat setempat. Kearifan lokal menjadi faktor penting dalam membangun kerukunan di Sumatera Utara. Kedua, penanganan melalui mediasi antara wilayah konflik dengan regulasi pemerintah. Namun hal ini sering kali bias karena program-program pemerintah yang hanya bersifat top-down, sehingga kerukunan yang tercipta tidak natural namun by design.

\section{Penutup}

Dari hasil penelitian ditemukan dua hal berikut. Pertama, idealita kerukunan yang dibangun oleh FKUB Sumatera Utara berpijak pada pola kerukunan non-pluralisme agama. Pola tersebut memiliki arti bahwa truth claim pada masing-masing individu agama tidak bisa disamakan karena memiliki landasan teologis yang berbeda antara satu dengan yang lainnya. Sebab, pluralitas atau keberagaman adalah suatu keniscayaan. Namun dalam konteks sosial, kebenaran teologis tersebut tidak boleh dipaksakan kepada orang lain, justru setiap individu beragama harus mampu bekerjasama dan sama-sama bekerja untuk kepentingan bermasyarakat, berbangsa dan bernegara. Kedua, dalam penerapannya, FKUB Sumatera Utara melakukan hal berikut: dialog teologis, interaksi sosial, advokasi dan regulasi serta dialog interaktif. Dialog-dialog merupakan bentuk preventif, yang bersifat tegas pada tataran teologis dan fleksibel pada tataran sosiologis dengan memberdayakan kearifan lokal masing-masing daerah. Sedangkan advokasi dan regulasi merupakan bentuk penanganan konflik melalui mediasi dan aturan hukum yang berlaku.

Dalam penerapan idealita kerukunan FKUB Sumatera Utara sebagaimana disebutkan, pemberdayaan kearifan lokal menjadi faktor penting terciptanya kerukunan, namun programprogram pemerintah hanya bersifat top-down sehingga seringkali tidak menyentuh secara langsung aspek tersebut. Karena itu, peneliti menyarankan untuk FKUB Sumatera Utara agar lebih meningkatkan potensi kearifan lokal masyarakat dengan tanpa mengurangi basis teologis yang diyakini oleh mereka, dan untuk pemerintah daerah agar melakukan kegiatan-kegiatan yang lebih menyentuh kepada akar rumput atau bersifat bottom-up. 
MIQOT Vol. XLI No. 2 Juli-Desember 2017

\section{Pustaka Acuan}

Ahmed, Akbar S. Postmodernism and Islam: Predicament and Promise. London and New York: Routledege, 1992.

Al-Harrani, Taqi' al-Dîn Abu al-'Abbâs Aḥmad bin 'Abd al-ㅂalîm Ibn Taymiyah, Majmu' Fatawa, Juz 18. T.t.p.: Dâr al-Wafa', 1426.

Arif, Syamsuddin. "Interfaith Dialogue dan Hubungan Antraagama dalam Perspektif Islam," dalam Tsaqafah: Jurnal Peradaban Islam, Vol. 6, Nomor 1, April 2010.

Arifinsyah. FKUB dan Resolusi Konflik: Mengurai Kerukunan antar Umat Beragama di Sumatera Utara. Medan: Perdana Publishing, 2013.

Aslan, Adnan. Religious Pluralism in Christian and Islamic Philosophy: the Though of John Hick and Seyyed Hossein Nasr, Curzon Press, 1998.

Bagus, Lorens. Kamus Filsafat. Jakarta: Gramedia Pustaka Utama, t.t.

Blackburn, Simon. Oxford Dictionary of Philosophy. Oxford: Oxford University Press, t.t.

BPS Provinsi Sumatera Utara. BPS-Statistics of Sumatera Utara Sumatera Utara dalam Angka/North-Sumatra in Figures. Medan: Penerbit BPS Sumatera Utara, 2013.

Bungin, Burhan. Analisa Data Penelitian Kualitatif: Pemahaman Filosofis dan Metodologis ke Arah Penguasaan Model Aplikasi. Jakarta: RajaGrafindo Persada, 2003.

Fatwa MUI No: 7/Munas/VII/MUI/II/2005 tentang Pluralisme, Liberalisme dan Sekulerisme Agama.

Harahap, AR. (ed.). Ensiklopedi Praktis Kerukunan Umat Beragama. Medan: Perdana Publishing, 2012.

Hick, John. Tuhan Punya Banyak Nama, terj. Amin Ma'ruf dan Taufik Aminuddin. Jakarta: Interfidei, 2006.

Hornby, A.S. Oxford Advanced Leaner's Dictionary of Corrent English. London: Oxford University Press, 1983.

Lumintang, Stervri. Teologi Abu-Abu (Pluralisme Iman). Malang: YPPII, 2002.

Madrasuta, Ngakan Made (ed.). Semua Agama tidak Sama. Medan: Media Hindu, 2006.

Muhajir, Noeng. Metodologi Penelitian Kualitatif. Yogyakarta: Raka Sarasin, 2002.

Schuon, Frithjof. The Transcendent Unity of Religions. T.t.p.: Quest Book Theosopical Publishing House, 1993.

Sibarani, Poltak YP., \& Bernard Jody A. Siregar. Beriman dan Berilmu: Panduan Kristen Pendidikan Agama Kristen untuk Mahasiswa. Jakarta: Ramos Gospel Publishing House, 2005.

Simamora, Elin, et al. Refleksi Forum Kerukunan Umat Beragama Provinsi Sumatera Utara sebagai Evaluasi Menuju Penyempurnaan Eksistensi. Medan: FKUB-SU, 2013.

Syaukani, Imam. Kompilasi Kebijakan dan Peraturan Perundang-Undangan Kerukunan Umat Beragama. Jakarta: Puslitbang, 2008. 
Manshuruddin: Pola Kerukunan Antar Umat Beragama dalam Perspektif FKUB

The New International Webster's Comprehensive Dictionary of The English Language. Chicago: Trident Press International, 1996.

Thoha, Anis Malik. Tren Pluralisme Agama: Tinjauan Kritis. Jakarta: Perspektif, 2007. 